\title{
The Construction of Program Knowledge Management Maturity Model-individual, Team, Organization Perspective
}

\author{
Nannan Guo1, Qinggang Fan ${ }^{2}$ and Hong $\mathrm{Yu}^{3,}{ }^{3}$ \\ ${ }^{1}$ Female, Hebe, Henan, China.Graduate student in zhejiang gongshang university. Research \\ direction:PM(project management). \\ ${ }^{2}$ Male, Heze, shandong, China.Graduate student in zhejiang gongshang university. Research \\ direction:PM(project management).
}

${ }^{3}$ Female, Shaoxing,Zhejang,China. Dean of school of international education in Zhejinag gongshang university.professor.Research direction:PM(project management).

*2391124911@qq.com

Keywords: Project group; Knowledge management; The ternary model; Control model; The maturity model

\begin{abstract}
With the changing of modern information technology, enterprises are taking new management techniques and means, in order to get sustainable competitive advantage. Project management and knowledge management $(\mathrm{KM})$ become an effective way to gain competitive edge. Through the research, knowledge management and the maturity of the related description, project group of knowledge management maturity model is preliminary explored.
\end{abstract}

\section{Introduction}

In an increasingly competitive global economy environment, more and more enterprises take project management as an effective way to gain competitive advantage [1].With its characteristics of dynamics, flexibility, project management provides a guiding framework for enterprise change [2] and becomes more and more favourable for enterprise managers. In order to solve many poor co-ordination problems between the project and the difficulty of choosing, project group of management arises at the historic moment [3]. It becomes the important way for enterprises to carry out the strategy of organization. At the same time, in order to improve the market reaction ability and competitive advantage, the enterprise take more and more attention to the effective management of its internal and external knowledge [4].Knowledge management involves all aspects of the buiness [5]. KMMM(Knowledge management maturity model), as the new development of theory of knowledge management, depicts the evolution of knowledge management in accordance with the specific path, from the initial, disorderly state of development to the mature and orderly stages of the process[6], and becomes the effective ways to measure project group of knowledge management level and promote to improve the project group of knowledge management ability.

\section{The Establishment of the Project Group of Knowledge Management Maturity Model}

On the basis of previous scholars' study, KMMM contains several different modules [7], in reference to the division of PMMM (project management maturity model)into different modules by Wang Liwen、Zhang Jincao [8], and combine with the building of knowledge management maturity model by Chen Yuqing [9], the knowledge management maturity model is divided into three aspects: the content of the category, grade and dimensions, as the core and foundation to establish KMMM.

On the basis of three aspects of the model, a group of knowledge management maturity structure of the project can be established. 


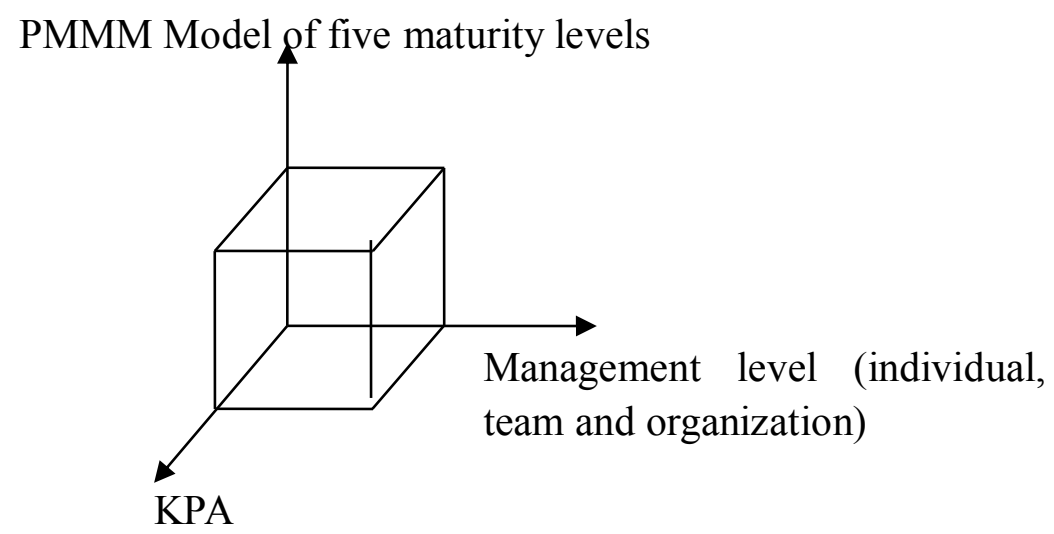

Figure 1. PMM Constructed model dimension of maturity

D - the Ternary Model of Knowledge Management. Individual, team and organization are the three basic levels of business activity, also it is on the three basic dimensions of knowledge management activities. Knowledge transmit among individuals, the project team and project organization. At the same time, it reflects the enterprise overall ability and level of knowledge management. Therefore it is necessary to build the corresponding model, from the perspective of individual, team and organization of the ternary group to study the level of knowledge management of the project.

Specific model is as follows:

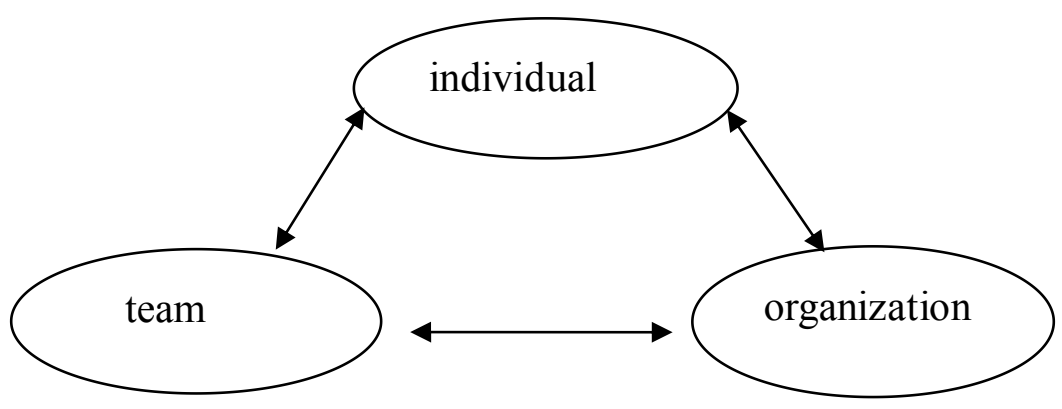

Figure 2.Project group of ternary model of knowledge management

The ternary model of knowledge management enriches the achievements of the related theory of knowledge management provides a new way for measuring the level of enterprise KM.

Analytical Model. Analysis model reveals the project group of key domain and key practices of knowledge management and indicates focus and activities. KPA refers to the main aspects of affecting project group of knowledge management performance, also, it is the main dimensions of the actual measurement.

Corresponding to each key process areas ,KPA can form a project group of knowledge management activities . 
Table $1 \quad$ KMMM process system

\begin{tabular}{|c|c|c|c|c|c|}
\hline \multicolumn{2}{|c|}{ Dimension } & Element & $\lambda$ & $\beta$ & $\gamma$ \\
\hline \multirow[t]{3}{*}{$\begin{array}{l}\text { Staff } \\
\text { A } \\
0.28 \\
85\end{array}$} & $\begin{array}{l}\text { individual } \\
\text { (I) }\end{array}$ & $\begin{array}{l}\text { Employee willingness to share } \\
\text { knowledge, cooperate with } \\
\text { management; } \\
\text { Members of the innovation and learning } \\
\text { ability; } \\
\text { Employee willingness to share } \\
\text { knowledge, cooperate } \\
\text { management; }\end{array}$ & $\begin{array}{l}0.1707 \\
0.1951\end{array}$ & $\begin{array}{l}0.0493 \\
0.0563\end{array}$ & $\begin{array}{l}0.1346 \\
0.1539\end{array}$ \\
\hline & team $(\mathrm{T})$ & $\begin{array}{l}\text { Senior management commitment and } \\
\text { support for knowledge management } \\
\text { team; }\end{array}$ & $\begin{array}{l}0.1533 \\
0.1568\end{array}$ & $\begin{array}{l}0.0442 \\
0.0452\end{array}$ & $\begin{array}{l}0.1426 \\
0.1459\end{array}$ \\
\hline & $\begin{array}{l}\text { organization } \\
\text { (O) }\end{array}$ & $\begin{array}{l}\text { General recognition of the value of } \\
\text { knowledge and understanding }\end{array}$ & $\begin{array}{l}0.1742 \\
0.1498\end{array}$ & $\begin{array}{l}0.0503 \\
0.0432\end{array}$ & $\begin{array}{l}0.1551 \\
0.1334\end{array}$ \\
\hline \multirow{3}{*}{$\begin{array}{c}\text { Tech } \\
\text { nolo } \\
\text { gycal } \\
\text { B } \\
0.23 \\
35 \\
\end{array}$} & $\begin{array}{l}\text { individual } \\
\text { (I) }\end{array}$ & Em & 0.1845 & 0.0431 & 0.2335 \\
\hline & team $(\mathrm{T})$ & $\begin{array}{l}\text { Relevant knowledge, skills training on a } \\
\text { regular basis }\end{array}$ & $\begin{array}{l}0.1586 \\
0.1456\end{array}$ & $\begin{array}{l}0.0370 \\
0.0340\end{array}$ & $\begin{array}{l}0.1217 \\
0.1118\end{array}$ \\
\hline & $\begin{array}{c}\text { organization } \\
(\mathrm{O})\end{array}$ & formal information technology sector & $\begin{array}{l}0.1618 \\
0.1812 \\
0.1683 \\
\end{array}$ & $\begin{array}{l}0.0378 \\
0.0423 \\
0.0393 \\
\end{array}$ & $\begin{array}{l}0.0739 \\
0.0828 \\
0.0768 \\
\end{array}$ \\
\hline \multirow{3}{*}{$\begin{array}{c}\text { Proc } \\
\text { ess C } \\
0.20 \\
80\end{array}$} & $\begin{array}{l}\text { individual } \\
\text { (I) }\end{array}$ & Communication skil & $\begin{array}{l}0.1798 \\
0.1514\end{array}$ & $\begin{array}{l}0.0374 \\
0.0315\end{array}$ & $\begin{array}{l}0.1129 \\
0.0951\end{array}$ \\
\hline & team $(\mathrm{T})$ & $\begin{array}{l}\text { Mature process design and } \\
\text { reengineering and continuously improve } \\
\text { ability; }\end{array}$ & $\begin{array}{l}0.1798 \\
0.1703\end{array}$ & $\begin{array}{l}0.0374 \\
0.0354\end{array}$ & $\begin{array}{l}0.1068 \\
0.1012\end{array}$ \\
\hline & $\begin{array}{c}\text { organization } \\
(\mathrm{O})\end{array}$ & Perfect knowledge diffusion strategies; & $\begin{array}{l}0.1451 \\
0.1735\end{array}$ & $\begin{array}{l}0.0302 \\
0.0361\end{array}$ & $\begin{array}{l}0.0947 \\
0.1133\end{array}$ \\
\hline \multirow{3}{*}{$\begin{array}{c}\text { Cont } \\
\text { ent } \\
\mathrm{D} \\
0.12 \\
86\end{array}$} & $\begin{array}{l}\text { individual } \\
\text { (I) }\end{array}$ & $\begin{array}{l}\text { The authenticity of information } \\
\text { obtained and get instant; } \\
\text { The authenticity of information } \\
\text { obtained and instant; }\end{array}$ & $\begin{array}{l}0.1601 \\
0.1524\end{array}$ & $\begin{array}{l}0.0207 \\
0.0196\end{array}$ & $\begin{array}{l}0.0660 \\
0.0626\end{array}$ \\
\hline & team $(\mathrm{T})$ & Effective management of knowledge; & $\begin{array}{l}0.1662 \\
0.1385 \\
\end{array}$ & $\begin{array}{l}0.0214 \\
0.0178 \\
\end{array}$ & $\begin{array}{l}0.0701 \\
0.0585 \\
\end{array}$ \\
\hline & $\begin{array}{l}\text { organization } \\
\text { (O) }\end{array}$ & $\begin{array}{l}\text { The tightness combination of } \\
\text { knowledge management strategy and } \\
\text { business strategy; }\end{array}$ & $\begin{array}{l}0.0330 \\
0.1108 \\
0.1385\end{array}$ & $\begin{array}{l}0.0171 \\
0.0142 \\
0.0178\end{array}$ & $\begin{array}{l}0.0447 \\
0.0373 \\
0.0466\end{array}$ \\
\hline
\end{tabular}

Maturity Level Determination - - the Control Model. Control model is one of the most important procedures for implementation of the project group of KMM model successfully and it can be based on the analysis of various index system of key domain model to evaluate the overall project group of knowledge management maturity level and indicate the key point of the development of the organization knowledge management. Also, it can indicate the direction for grades. Control model can be analyzed by quantitative research method.

Research method. Elements of two comparative importance rating and assignment 


\begin{tabular}{|c|l|c|}
\hline $\begin{array}{c}\text { numerical } \\
\text { order }\end{array}$ & importance rating & $\begin{array}{c}a_{i j} \\
\text { assignment }\end{array}$ \\
\hline 1 & $\mathrm{i}, \mathrm{j}$ equal importance & 1 \\
\hline 2 & $\mathrm{i}$ more importent & 3 \\
\hline 3 & i much more important & 5 \\
\hline 4 & j more importent & $1 / 3$ \\
\hline 5 & $\mathrm{j}$ much more important & $1 / 5$ \\
\hline
\end{tabular}

$a_{i j}=\{2,4,1 / 2,1 / 4\}$ indicates the importance level among $a_{i j}=\{1,3,5,1 / 3,1 / 5\}$

(1) analysis of expert evaluation judgment matrix is as follows :

$M=\left[\begin{array}{cccccc}1 & 1 & 2 & 2 & 4 & 4 \\ 1 & 1 & 1 & 2 & 3 & 3 \\ 1 / 2 & 1 & 1 & 2 & 3 & 3 \\ 1 / 2 & 1 / 2 & 1 / 2 & 1 & 2 & 2 \\ 1 / 4 & 1 / 3 & 1 / 3 & 1 / 2 & 1 & 1 \\ 1 / 4 & 1 / 3 & 1 / 3 & 1 / 2 & 1 & 1\end{array}\right]$

(2)

$\overline{W_{1}}=\sqrt[n]{\prod_{j=1}^{n} b_{i j}}, \quad i, j=1,2 \ldots ., n$

Results: $\overline{W_{1}}=2, \overline{W_{2}}=1.66887, \overline{W_{3}}=1.44225, \overline{W_{4}}=0.89090, \overline{W_{5}}=0.49028, \overline{W_{6}}=0.49028$

(3) The vector normalization : $w=\left[w_{1}, w_{2}, w_{3}, w_{4}, w_{5}, w_{6}\right] T$

results: $W_{1}=0.2885, W_{2}=2335, W_{3}=0.2080, W_{4}=1286, W_{5}=0.0707, W_{6}=0.0707$

(4) The biggest feature is:

$\lambda_{\max }=\sum_{i=1}^{n} \frac{(M W)_{i}}{n W_{i}}=6.0521$

(5) $C I=\frac{\lambda_{\max }-n}{n-1}=0.01042$

(6) $C R=C I / R I=0.0084$ consistency is good.Therefore, $w_{i}$ is the value of the first layer of the weight of each factor.

The second layer: to affirm the target weights of the

The weight of each factor in the second layer: $\lambda_{a k}=\frac{1}{\sum_{1}^{6} \overline{X_{J}}} \overline{X_{J}}$

\section{Conclusion and Prospects}

The model of KMMM provides a theoretical framework for measuring project organization level of KM . Starting from individual, team and organization, this paper builds the knowledge management consists of temary model, analysis model and control model. Through this model, measuring the level of KM in project type organization can be not only from people, technology, process but from six key domain dimensions. At the same time, the index system of measuring and the final model still need further verification in practice and become a direction of further research. 


\section{Acknowledgements}

This work was supported by ZheJiang Provincial natural science foundation（LY13G020007）.

\section{References}

[1] Grant K P, Pennypacker J S, Project Management Maturity: An Assessment of Project Management Capabilities Among and Between Selected Industries[J], IEEE Transactions on Engineering Management, 2006, 53 (1), 59-68.

[2] McKenna L. Managing Change Through Project Management: A Practitioners Guide, Lindsay McKenna, 2002.

[3] Shi Wen Geng xi-quan Wang, zhangYang .Based on the project group of management of the enterprise strategy implementation of the research [J]. Statistics and Decision,2009,(4) : 166-167.

[4] Ping Jung Hsieh, Binshan Lin, Chinho Lin. The Construction and Application of Knowledge Navigator Model: An Evaluation of Knowledge Management Maturity[J].Expert System with Applications, 2009,36(2): 4087-4100.

[5] Wu, W., \& Lee, Y. Selecting knowledge management strategies by using the analytic network process. Expert Systems with Applications, 2007,32(3), 841-847.

[6] Herbsleb, J., Zubrow, D., Goldensen, D., Hayes, W., and Paulk, M. Software Quality and the Capability Maturity Model [J], Communications of the ACM, 1997.40 (6):30-40.

[7] Kevin, C. D., Knowledge Management Maturity Mode: theoretical development and preliminary empirical testing [D]. Chicago: University of Illinois at Chicago, 2006.

[8] Li-wen wang, Zhang Jincao. Researching the construction of project management maturity model [J]. Journal of information science: 2009: 70-71.

[9] Chen Yuqing. Knowledge management maturity model (KMMM) research review [J]. Journal of technology economy and management research, 2009,02:67-70.

[10] Lee J N, Kwork R C W. A fuzzy Gss framework for organizational knowledge acquisition [J], International Journal of Information Management, 2000, 20(1): 383-398. 